\title{
Chapter 6 \\ Puncturing Parts of History's Blindness: South Saami and South Saami Culture in Early Picture Postcards
}

\author{
Cathrine Baglo
}

\begin{abstract}
In this chapter, I discuss early picture postcards of South Saami and South Saami culture from approximately 1880-1950. The point of departure is Troms $\varnothing$ University Museum's collection of more than 3800 postcards with Saami motives as well as the postcard exhibition 'With an eye for the Sámi' at Perspektivet Museum in the same city. While postcards of Saami have a bad reputation as objects of contempt or symbols of oppression, I emphasize their potential as historical sources. How picture postcards are technologies of memory that may help reclaim a hidden or lost past, providing both personal and collective value as they open up discussions related to colonization and decolonization.
\end{abstract}

Iktedimmie Daennie tjaalegisnie digkedem aareh påastekåarhth ovrehte jaepijste 1880-1950 åarjelsaemijste jïh åarjelsaemien kultuvreste. Våarome lea Romsan universiteeten museumen våarhkoe vielie goh 3800 påastekåarhtigujmie saemien motijvigujmie jïh aaj dihte påastekåarhtevuasahtalleme man nomme 'Med blikk for det samiske' Perspektivet Museumisnie seamma staaresne. Mearan påastekåarhth saemijste aktem nåake såaltjem utnieh goh ålkoestamme objekth jallh goh diedtelamme symbovlh manne dejtie nuhtjem goh histovrijen gaaltijh. Manne goerehtem guktie påastekåarhth leah mojhtesekåarhth mah maehtieh viehkiehtidh aktem tjeakoes jallh teehpeme åvtetje aejkiem bååstede åadtjodh, jïh dovne persovneles jïh ektie aarvoem vedtieh gosse dah digkiedimmine åtnasuvvieh mah leah kolonialiseradimmien jïh dekoloniaseradimmien bïjre.

\subsection{Invisibility and Ignorance}

In February 2018, the same week as the Saami National Day, the popular Friday night TV show Nytt på nytt (Norwegian version of 'Have I Got News for You') on the state-owned Norwegian Broadcasting Cooperation (NRK) featured a Saami commentator for the first time. The commentator, Ronald Pulk, a North Saami jour-

\footnotetext{
C. Baglo (凶)

Troms $\varnothing$ University Museum, UiT-The Arctic University of Norway, Troms $\varnothing$, Norway e-mail: cathrine.baglo@uit.no 
nalist and comedian, is known to Saami speaking TV audiences as the host of the talk show Studio Sápmi. The Norwegian audience, however, may have recognized him from Reinflytting minutt for minutt (Reindeer-herd migration minute by minute), a live slow TV show produced by NRK Sápmi in 2017 which also made media history by drawing an unexpectedly large number of viewers, Saami and non-Saami alike, to the screen. While the Nytt på Nytt cast celebrated Pulk's guest appearance, other TV channels and programmes paid more or less successful tributes to Saami culture, language and history the same week, and also expressed embarrassment over Norwegian ignorance of anything Saami. 'I know how to order a beer in all kinds of languages, even Eritrean,' one of the hosts pointed out, 'but I have no idea how to order a beer in Saami'.

The Saami language in question is of course North Saami. The North Saami constitutes the majority population among the Saami indigenous minorities within the Norwegian state. Public knowledge of South Saami culture, language and history is even less. This lack of knowledge also includes South Saami imagery. Before Tråante in 2017, the centennial for the opening of the first Saami congress in Trondheim on 6 February 1917, a date that has since become the Saami National Day, many Norwegians had never before seen a South Saami costume. During Tråante, Trondheim was swamped by festively dressed Saami, and the activities that took place were broadcasted both nationally and internationally. The purpose of Tråante was to give people a better understanding of the Saami and their culture and history over the 100 years that had passed. Tråante is a watershed moment in the history of both Norwegians and Saami, South Saami in particular, as they became visible for the first time on the national stage.

Images of South Saami and South Saami culture are the subject of this chapter. The images in question are early picture postcards from approximately 1880-1950, a historical period heavily marked in Norway by the nation state's systematic and intensifying cultural assimilation of the Saami (Minde 2005, 7-12). ${ }^{1}$ In Sweden, a segregation policy focused on the Saami was implemented in the same period, more precisely focusing on the nomadic reindeer herding mountain Saami. Reindeer herding forest Saami, Saami who fell out of the industry or subsisted on other means were not considered Saami and attempts were made to assimilate them into the Swedish population (Lantto 2000, 41-47). Picture postcards, however, have a bad reputation, and in particular, picture postcards which may loosely be lumped together as 'ethnographic' or 'anthropological'. The above-mentioned period was also the heyday of postcard production. During the late nineteenth and early twentieth centuries, millions of picture postcards of exotic cultures were produced for Western consumption (Geary and Webb 1998). This commercial production notwithstanding, picture postcards have an often unacknowledged potential as culture historical sources bringing back incidents, old encounters, stories of individuals and cultural expressions that have been overlooked or lost, and can also disrupt dominant colonial narratives

\footnotetext{
${ }^{1}$ According to Minde, the Norwegianization of the Sámi is divided into four phases, three of which are of importance here: 1870/1905, (introduction and) consolidation, 1905-1950, culmination, 1950-1980, dissolution.
} 
attached to colonial ways of looking at and representing the Saami. It is this potential I intend to explore in this chapter: How picture postcards are technologies of memory that may help reclaim a hidden or lost past, providing both personal and collective value as they open for discussions relating to colonization and decolonization.

The point of departure is the Saami postcard collection at Troms $\varnothing$ University Museum. ${ }^{2}$ The collection consists of 3840 postcards, both picture postcards and illustrated postcards, which I curated for digital use in 2011-2012. The collection was assembled by Haakon Kierulf, a lawyer settled in Alta and Oslo, Norway, and is available through the Norwegian University Museum's photo website. ${ }^{3}$ The motifs are from Norway, Sweden and Finland, a few are from Russia, and they date from the late 1860s until approximately 2000. I have identified a little over 200 postcards out of the total number of 3840 as South Saami. Almost all of them were produced in Sweden, a point I will return to below. The low number reflects the fact that the South Saami are a minority within the minority and their associated lack of public visibility. In addition, I will draw on postcards with South Saami motives from the Alan Borvo collection owned by Jelena and Nils John Porsanger in Kautokeino. ${ }^{4}$ In November 2017, Perspektivet Museum in Troms $\varnothing$, northern Norway, opened the exhibition 'With an eye for the Saami' (Med blikk for det samiske) based on Borvo's postcard collection. ${ }^{5}$ The objective is to identify motifs I find to be prevailing, but I also point to differences and similarities within the collection as a whole and in comparison with other postcards or photographs. As is the case for most ethnographic photographs, the majority of Saami picture postcards are based on photographs taken by outsiders. There are, however, some significant exceptions, such as the South Saami photographer Nils Thomasson. In fact, Thomasson is accountable for more than half the postcards in the Troms $\varnothing$ Museum collection with South Saami motifs. A closer look at Thomasson's activities is therefore justified. For this reason, the postcards testify not only to the majority society's popular perception of South Saami identity and culture of the time, perceptions that might resonate, or not, with dominant public and scientific perceptions problematized in this volume, they may also reveal information about Saami self-expression.

\subsection{The Bad Reputation of Picture Postcards}

The bad reputation of picture postcards is of course due to photographs' colonial role as technologies of cultural appropriation, racism, denigration, sexual exploitation, assimilation and misrepresentation (see for example, Alloula 1986; Edwards

\footnotetext{
${ }^{2}$ The collection was assembled by Haakon Kierulf, a lawyer settled in Alta and Oslo, Norway, and is available through the Norwegian University Museum's photo website (www.unimus.no).

${ }^{3}$ https://www.unimus.no.

${ }^{4}$ Alan Borvo (1933-2002) was a Frenchman who over a period of many years collected thousands of postcards from all over the Sámi area after having visited Finnmark as a young student in the 1950s. He later gave the collection to Elena and Nils Porsanger.

${ }^{5}$ https://www.perspektivet.no/utstillinger/med-blikk-for-det-samiske/.
} 
1992; Faris 2003; King and Lidchi 1998), but also due to their connection to commercialism and popular culture (see for example, Rydell 1998; Maxwell 1999). It seems indicative of this negative understanding that postcards have not been considered historically significant and information has not been collected, catalogued or housed as with other historical material until recently (see for example, Woody 1998, 22). As pointed out by art historian Sigrid Lien, taking into consideration the Saami ethnopolitical movement that began to take form in the 1960s and 1970s, postcard representations came to be considered as objects of contempt or symbols of oppression (Lien 2017, 210). 'Postcard-Saami is a notion, you know,' a curator later explained to her and social anthropologist Hilde Nielssen during their study of the use of photography at RiddoDuoattarMuseat-Saamiid Vuorká-Dávvirat in Karasjok, Northern Norway (Lien and Nielsen 2012, 299). 'For the Saami, "postcard" used to be a term of abuse,' the curator continued referring to the way photography has been misused in the name of science, 'you know, with measuring skulls and so on'. One of the first to voice this view was the Saami multimedia artist Nils Aslak Valkeapää. Commenting on the irony in the title of his book, Greetings from Lapland (originally published in Finnish in 1970) and the practice of producing postcards masquerading non-Saami as Saami, Valkeapää explains: 'The title comes from the innumerable postcards which attempt to depict Samiland and the Samis. Almost all of them are dreadful, insulting: non-Samis in thoroughly tasteless, ugly imitations of Sami dress' (Valkeapää 1983, 1; Lien 2017, 10).

\subsection{Producing Imagined Saaminess}

There are indeed postcards in the Troms $\varnothing$ Museum collection that fit Valkeapää's description. Perspektivet Museum plays on this by showing the worst card first, having a highly caricatured, spiteful postcard manipulated beyond recognition by the publisher introducing the exhibition, as if to disarm the visitor and confront their expectations right away. Especially noticeable in relation to South Saami motifs in both collections, and quite substantial in numbers, is a series of hand-tinted postcards of attractive young girls and women in South Saami gapta, or costumes resembling the gapta, a belted woollen dress with a v-shaped opening, in these cases festively decorated with silver jewellery. ${ }^{6}$ Some of the girls and women have braids, many have curls, on some the hair hangs loose. The hats resemble but deviate from traditional South Saami hats. Almost all the postcards carry the inscription 'Lappland' (Land of the Saami) or 'Sweden, province of Lappland'.

The postcards in this series are based on studio photographs, most likely cabinet cards produced around 1880 or 1890 , perhaps a little later. The cabinet card was

\footnotetext{
${ }^{6}$ At the Troms $\emptyset$ University Museum collection, see for example, tslp13186, 12431, 12430, 10596, 10954, 10948, 10945, 10944, 10943, 10942, 10941, 10940, 10931, 10930, 10928, 10923, 10921, 10919, 10918, 10769. These are colourized postcards, some exist in several versions, including black and white.
} 
a format widely used for photographic portraiture after 1870 . The large size made them easy to work with and suitable for retouching. Colourizing was especially used to highlight such details as the costumes. Where the publishers are known, they are Swedish, such as John Fröberg, Sweden's first mail order company established in south-eastern Sweden in 1879, and Paul Heckscher, a dealer in cards and art reproductions based in Stockholm from 1900 to 1917. The sitters pose in a dignified manner in accordance with the conventions of late nineteenth-century bourgeois studio photography. Many of them appear winter fresh and self-assured; ready to conquer the world. They pose with skis, ski poles or walking sticks, with snowballs ready to throw or are holding the rail fence typical of the outdoor environment. Not surprisingly, many of the postcards with wintery motifs have been used as Christmas cards. Although postcards were also bought as souvenirs and collectibles, the majority of Norwegian and Swedish postcards produced in this period were used as Christmas or New Year's cards, a fact that influenced the development of the motifs (Ulvestad 2005). Other sitters are smoking a pipe or reading fortunes in coffee grounds. Interestingly, however, the women are probably not Saami. Rather, they are non-Saami pretending to dress as Saami (Fig. 6.1).

In her article 'Assimilating the wild and primitive: Lajla and other Saami heroines in Norwegian fin-de-siècle photography', Sigrid Lien identifies a practice where
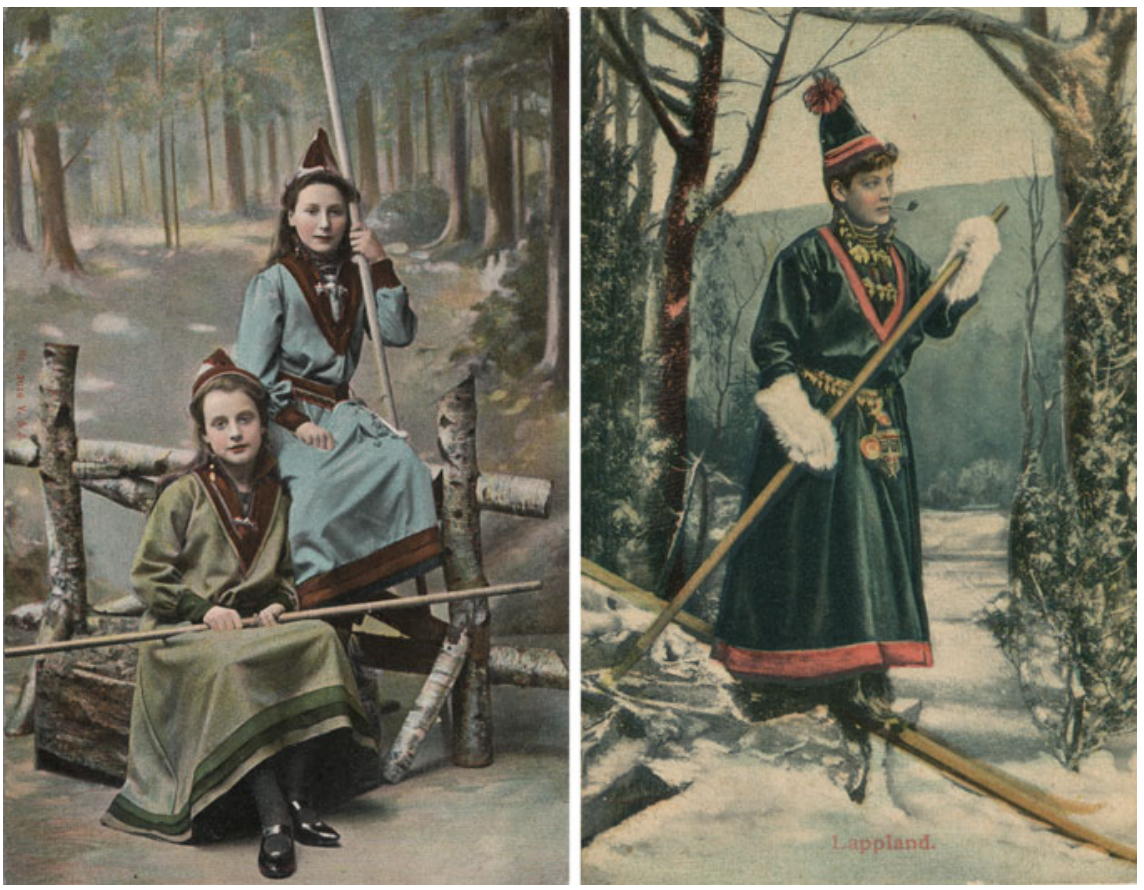

Fig. 6.1 Women and girls posing in South Saami-like costumes. Source Troms $\varnothing$ University Museum (tslp10954 and tslp10924) 
Norwegian middle-class women at the turn of the nineteenth century visited photographic studios where they would have their image produced wearing Saami costumes or costumes reminiscent of the Saami (Lien 2017, 211-212). One such place was the photographic studio established by the Persen sisters ${ }^{7}$ in Bergen, Norway in the 1880s, another the studio of the photographer Solveig Lund in Moss and Kristiania (Oslo), where she worked until 1906. After that, she limited her business to colourizing photographs and postcards based on her previous glass plate negatives. ${ }^{8}$ Particularly, interesting in relation to my investigation are the Persen sisters, who were born in Stavanger but trained as photographers in Stockholm. Their signature products, directed at the booming tourism industry and local middle-class consumers, were images of hand-tinted photographs of attractive young girls and women wearing Norwegian national costumes (Bonge 1980, 325 in Lien 2017, 212).

As pointed out by Lien, this repertoire also included Saami costumes, more specifically, the South Saami costume as demonstrated in a cabinet photograph the Persen sisters produced in $1896 .{ }^{9}$ The use of costumes reminiscent of the South Saami may of course be related to geographical circumstances. The South Saami population was closest to Bergen where the Persen sisters had their studio. More important perhaps was the fact that South Saami images, not North Saami images as today, seem to have dominated the postcard market around the turn of the century, generated not least by mass-producing publishers in Southern Sweden and Stockholm where the Persen sisters had trained. Moreover, and as also pointed out by Lien, a ski suit with elements that referred to the South Saami costume were in vogue for Norwegian middle-class women around the same time. Eva Nansen, the wife of the famous arctic explorer Fridtjof Nansen, was important in this regard. She captured public attention in 1890, when she skied with her husband wearing this suit. The incident was preserved for posterity in a series of photographs Ludwik Szacinski produced of Eva Nansen alone and with her husband. ${ }^{10}$

\subsection{Cultural Assimilation as Women's Liberation}

Lien interprets the photographs of non-Saami women in Saami-like costumes in light of a larger romantic but also inherently discriminating movement fuelled in particular by a story published in 1881 by Jens Andreas Friis, the first professor of the Saami language in Norway. The main protagonist was Lajla, a Norwegian merchant's daughter who grew up among the North Saami in Finnmark. As a young woman, Lajla had to choose between marrying a Saami or a Norwegian. Typical of the time, Friis

\footnotetext{
${ }^{7}$ Jenny (1863-?) and Thoma Henrikke Persen (1867-1913). Lien (2017, 212).

${ }^{8} \mathrm{https}: / /$ norskfolkemuseum.no/solveig-lund.

${ }^{9}$ Young Girl in Sámi Costume, approx. 1896. Cabinet card photograph. Lien $(2017,209)$.

10 "Eva og Fridtjof Nansen på ski, 1890”. Photo: L. Szacinski/National Library, Norway, bldsa_7a006. "Eva Nansen på ski, 1889”. Photo: L. Szacinski/National Library, Norway, bldsa_7a013.
} 
emphasizes the racial inferiority of the Saami, while simultaneously idealizing the reindeer herding life. The effect of Saami culture on Lajla, however, is portrayed as solely beneficial. The story was adapted for the cinema three times, in 1929, 1937 and 1958. In the 1929 silent film by Danish-Finnish director George Schneevoigt, Lajla beats male competitors in reindeer races, canoes steep river falls and climbs trees with ease and grace. While the story of Lajla was translated into English, Swedish, Dutch and French, the 'Lajla fascination', Lien convincingly argues, was supported and substantiated both nationally and internationally by a massive production of visuals, including photographs, postcards and film (Lien 2017, 221). ${ }^{11}$

These visuals not only contributed to turn Saaminess and Saami culture into a commodity, Lien also sees the postcards or photographs of non-Saami women wearing Saami costumes as a particular kind of cultural appropriation. In this case, the colonial tropes worked as metonymy of freedom for part of the colonizing population, the socially and politically restricted Norwegian middle-class women. At the same time that the Norwegian state promoted a politics of assimilation as part of the nationbuilding process, photographers, some of them women, were making a living selling pictures of women and children dressed as Saami, while female sitters would pay to have such a photograph taken. Paradoxically, they were doing this at a time when the Norwegian government was doing its best to erase the Saami people's Saaminess (Lien 2017, 215).

\subsection{Producing Picturesque Types}

As pointed out at the Perspektivet exhibition, exaggerations and stereotypes dominated the early postcard industry. Geographic and cultural distance left their mark on the motif, as did political and ideological conditions. Postcards produced by international publishers for tourists and collectors tended to be particularly conventionalized and stereotypical, while national or local postcards were more idiosyncratic in their depiction of various themes of importance to consumers (Geary and Webb 1998, 2).

A postcard comparable to the women in South Saami and South Saami-like costumes is a hand-tinted studio postcard from approximately the same period (Fig. 6.2). It shows two men reading books in front of an idyllic forest scene with a burbling creek. The atmosphere of the image is again one of dignity. The men are completely absorbed in their reading. One of them is leaning against the trunk of a tree and the other is casually lounging on the (reindeer) hide they are sitting on. The postcard has been used as a Christmas card and the publisher is again Fröberg in Finspång. A black-and-white version exists as well as a modern remake advertising for Dundret Ski Resort in Gällivare in Norrbotten in Sweden, in other words outside the South

\footnotetext{
${ }^{11}$ In 1929, the Danish-Finnish director George Schneevoigt adapted the story for the silent screen, in 1937, the same director made a Swedish-Danish version, while a third version, a Swedish-German co-production, was made in 1958 by Rolf Husberg. Regarding the Lajla fascination reflected in postcards, see also Ulvestad (2005, 25). Six postcards with motifs from the 1929 and 1937 versions are in the Tromsø Museum collection.
} 


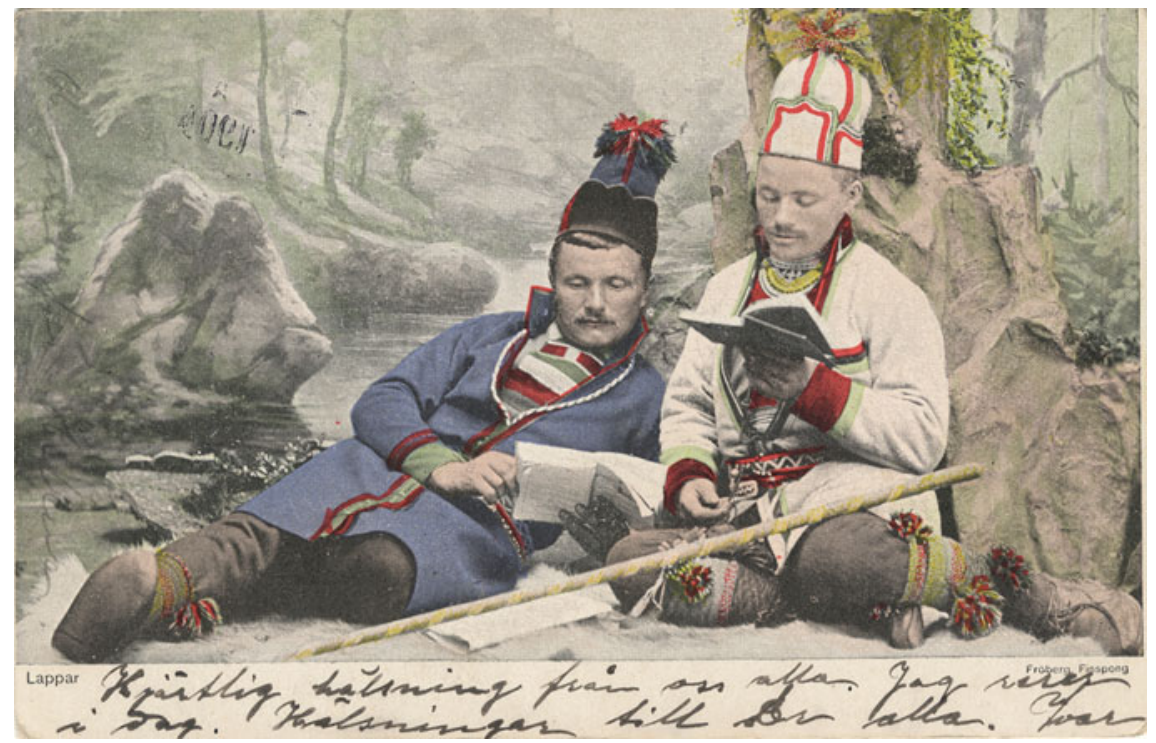

Fig. 6.2 "Lappar" (Laplanders). Postcard published by Fröberg, probably around 1880-1890. Source Troms $\emptyset$ University Museum (tslp 10953)

Saami area. The remake carries the following inscription translated from Swedish: 'The original. Waiting for After-Ski. Dundret-so laid back'.

In contrast to the costumes of the women and young girls in the previous postcards, this postcard shows authentic South Saami costumes. The hand-tinting makes the men's different breast cloths, boenge-skuvmie, easily distinguishable. The motif may in part be understood as a costume picture, a cataloguing of different kinds of costume styles in different regions. This was already an established genre which started in painting but became popularized in Norway through travelling photographers, such as Marcus Selmer (1819-1900) from the 1850s, and then it was closely related to a romantic nationalist wave and the construction of a national identity (Larsen and Lien 2007, 82-89). Selmer was a Danish-born photographer and the first to open a studio in Bergen. As pointed out by Lien, by the end of the nineteenth and beginning of the twentieth centuries, the postcard became a major arena for the visual rhetoric of nationalism (Lien 2017, 213).

An example of Selmer's photographic costume study is the cartes de visite 'Fin from Helgeland in Nordland'. ${ }^{12}$ Helgeland is an area in the northern part of Norwegian South Saami lands. The photograph, however, was not taken in Helgeland. It was taken in Bergen where Selmer had his studio, and the sitter had most likely travelled the more than $1000 \mathrm{~km}$ to sell fish or pursue other business. Similar to the photographer behind the postcard published by Fröberg, Selmer used props to add local character to the picture, such as the stick which also features on the postcard

\footnotetext{
${ }^{12} \mathrm{https} / / /$ digitaltmuseum.no/011013410241/52-fin-fra-helgeland-i-nordland.
} 
of the two men. In contrast to the postcard, however, the costume-dressed man from Nordland is posing against a neutral background. Only the carpet on Selmer's studio floor is visible. In the studio postcard, the sitters are presented in front of a painted background considered correct or fitting to 'root' the documentation, in this case a forest. This is also typical of the time as the construction of identity was largely connected to landscape, which was considered a key to understanding the characters of the people (Larsen and Lien 2007, 85). In Norwegian costume photographs for example, landscape paintings of mountains were frequently used as backgrounds. At the fin de siècle, mountain people or people of the outdoors, the peasants, but the Saami too, were considered unspoiled, healthy, strong and good-natured.

It is, however, tempting to interpret the motif in light of the missionary efforts by the Swedish church. It is probably not just any random books they are reading, but the bible and the catechism. Every member in a congregation would be examined in the catechism on a regular basis. In Sweden, the results were reported in the husförhörslängd (house enquiry register) and in Norway in the parish register, both important historical sources and especially with respect to investigations of Saami communities where such sources are sparse. The stick in the postcard might of course indicate that they are reindeer herders, a popular motif in the representation of the Saami, ${ }^{13}$ but it might also double as an allegory for piety. At any rate, there is more going on in this postcard than the documentation of costumes or a national type. As mentioned above, this also included at the time the Saami. They were one among several peoples that formed part of a composite kingdom (Kjeldstadli 2010, 24). As pointed out by Lien, in their photographic conquest of Norway, the first generation of travelling photographers, such as Selmer, represented the lower social classes, farmers and fishermen through the same kind of ethnographically or typologically classifying gaze (Lien 2017, 215). Later it was proposed that the Saami were a foreign race that did not belong in Scandinavia (see for example, Baglo 2001a, b).

The postcard of the two men may also be perceived as an expression of a coexisting sentimental genre of a more international character where picturesque types of different kinds became popular motifs. In her book on European and South American depictions of Andean indigenous groups from the late eighteenth to the early twentieth centuries, anthropologist Deborah Poole identifies the Indian brigand, the water carrier, the porter and the lice-picker as recurring types (Poole 1997). The typologically classifying gaze on the postcard of the two South Sámi men is supported by the caption. While the caption on Selmer's cartes de visite, 'Fin from Helgeland in Nordland', is typologizing, it at least mentions roughly the origin of the sitter. The origin of the sitters of the postcard is not specified at all. They are just Sámi-or 'Lappar' which also for contemporary viewers has served to obscure cultural variety and reduce the Sámi communities to one undifferentiated group. Quite significant differences, such as the fact that a North Sámi speaker can barely understand a South Sámi, are removed with the brush of a pen. Other recurring picturesque types which often overlap with the ethnographically classifying types, or they feed off each other,

\footnotetext{
${ }^{13}$ A search using "herder" (gjeter) in the Troms $\emptyset$ Museum Sámi postcard collection gave 22 hits but more motifs should probably be classified with this entry word.
} 
include Saami children, especially girls, ${ }^{14}$ Saami mothers holding small children in the Saami cradle made of a trunk of a tree, in South Saami gïerhkeme,${ }^{15}$ Saami women weaving shoe ribbons, ${ }^{16}$ Saamis working the hay or grass as insulation in the shoe, ${ }^{17}$ Saami weddings, ${ }^{18}$ Saamis drinking coffee ${ }^{19}$ and Saamis smoking pipes, both men and women. ${ }^{20}$ Sometimes the types turn into the grotesque. This is especially the case for the popular pipe-smoking motif, easily identified in other parts of the world and with other people. While this juxtaposition of indigeneity with technologies associated with modernity is a typical colonial trope, Lien demonstrates that the female stereotypes of northern colonialism included both the charming backwardness of the innocent child of nature, the noble savage, but also 'the unruly, gender-transgressive, pipe-smoking, wild-woman' (Lien 2017, 217).

Another postcard within the staged studio portrait of the fin de siècle shows two men, a woman and a child drinking coffee (Fig. 6.3). They are sitting on the ground with legs crossed holding their china cups. The woman is ready to pour coffee from a copper kettle centrally placed on a make-believe open fire. The boy is looking at her in anticipation. The woman's sïlpe-gåahke, silver collar, is another salient feature, as well as the shoe ribbons, the men's two types of breasts cloths and two types of hats, the snijpetjohpe with the visor to the right and the stielietjohpe to the left, which have been colourized. The backdrop illustrates a forest. Another postcard in the collection features the same group, but in different poses. ${ }^{21}$ While the photographer is unknown, the postcard was published by Ernst G. Svanström in Stockholm.

The motif of the coffee drinking Saami invokes a similar kind of portrait typical to the photographic bourgeois aesthetics of the time, where the coffee table and other furniture were carried into the garden outside the villa or the farmhouse (Larsen and Lien 2007, 56). While these kinds of photographs express the tension between the traditional and the modern in a way similar to the smoking Saami, the difference between the bourgeois aesthetics and the postcard of the South Saami is of course the lack of a house, furniture and cultivated landscape. Moreover, similar

\footnotetext{
${ }^{14}$ A search using "girl" in the Tromsø Museum Sámi postcard collection gave 419 hits but not all of these are portraits.

${ }^{15}$ A search using "woman" (kvinne) and "cradle" (komse) in the Troms $\varnothing$ Museum Sámi postcard collection gave approximately 40 hits when I excluded the photographs that show larger groups or families and are not focused on the mother and child only. A South Sámi example that seems to feature the fathers is tslp10855.

${ }^{16}$ A search using "woman" (kvinne) and "weaving” (veving) in the Tromsø Museum Sámi postcard collection gave 11 hits, a few of them are different versions of the same postcard.

${ }^{17}$ A search using "blister sedge" (sennegress) in the Troms $\emptyset$ Museum Sámi postcard collection gave 18 hits, a few of them are different versions of the same postcard. A South Sámi example is tslp10855, "Lappkvinna med skohöi".

${ }^{18}$ A search using "bridal couple" (brudepar) in the Tromsø Museum Sámi postcard collection gave 33 hits, a South Sámi example seems to be tslp12335, "Lappbröllop".

${ }^{19}$ A search using "coffee cup" (kaffekopp) in the Tromsø Museum Sámi postcard collection gave 14 hits.

${ }^{20}$ A search using "pipe” (pipe) in the Tromsø Museum Sámi postcard collection gave 102 hits, a little less than half show women smokers.

${ }^{21}$ Tslp10926.
} 


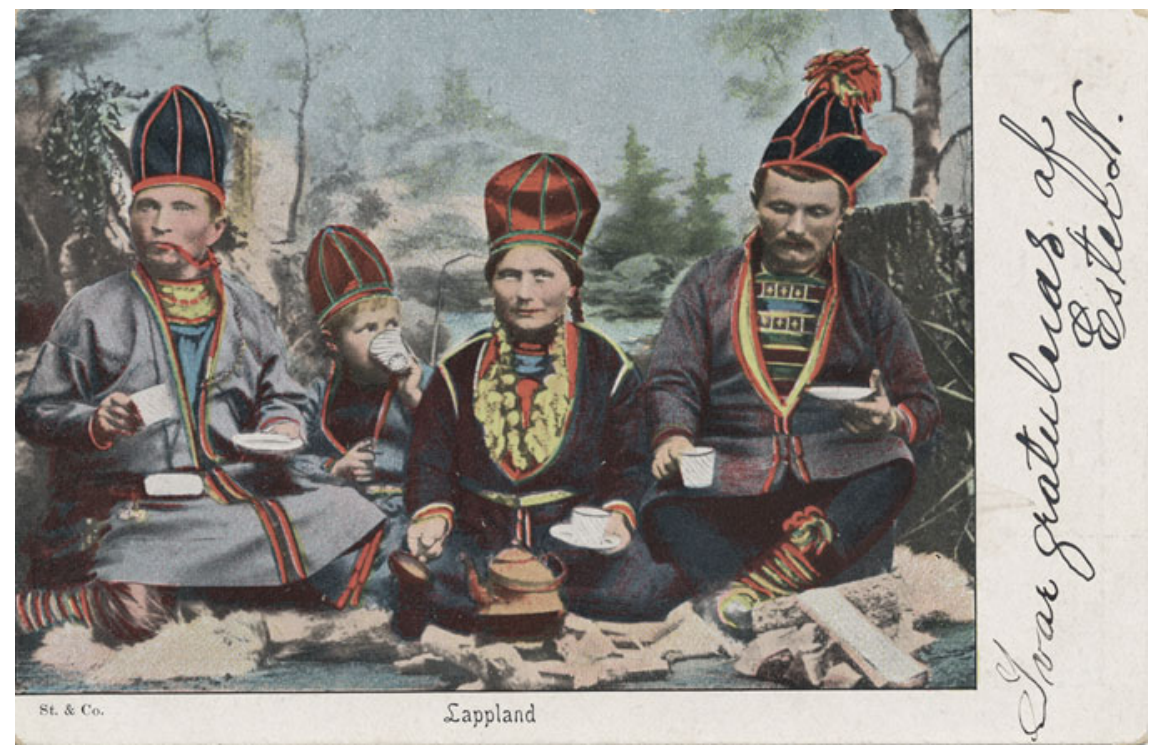

Fig. 6.3 'Lappland'. Hand-tinted postcard. Publisher unknown. Source Troms $\varnothing$ University Museum (tslp 10119)

photographs of Swedish and Norwegian sitters were only by exception turned into a postcard, and in this case a greeting card: to 'Ivar' from 'Ester N'. The image is visually interesting. While the males' and the boy's gazes are disengaged or looking elsewhere, the woman calmly meets the look of the viewer. She appears confident, expectant and in charge. In an article on the Greenlandic photographer John Møller (1867-1935), the art historian Ingeborg Høvik has discussed the enactment of gender in photography, including Szacinski's above-mentioned portrait of the Nansens. Although Eva Nansen is included in the portrait of her husband, she is clearly a sideshow - an attribute. His physical and psychological presence in the photograph is much stronger (Høvik 2016, 177). In the South Saami postcard, gender is acted out differently.

\subsection{Idiosyncratic Depictions}

There are also examples in the collection of postcards of a more idiosyncratic and specific character. One example is 'Lappläger vid Kolåsen' (Saami camp at Kolåsen) based on a photograph by the Stockholm photographer Gösta Florman (Fig. 6.4). The photograph, from the 1890s, shows a large group of Saami from Offerdalen, a highland region situated $50 \mathrm{~km}$ north-west of Östersund, attending mass at Kolåsen Saami Chapel in Kall. The caption, Saami camp at Kolåsen, is in other words at best 


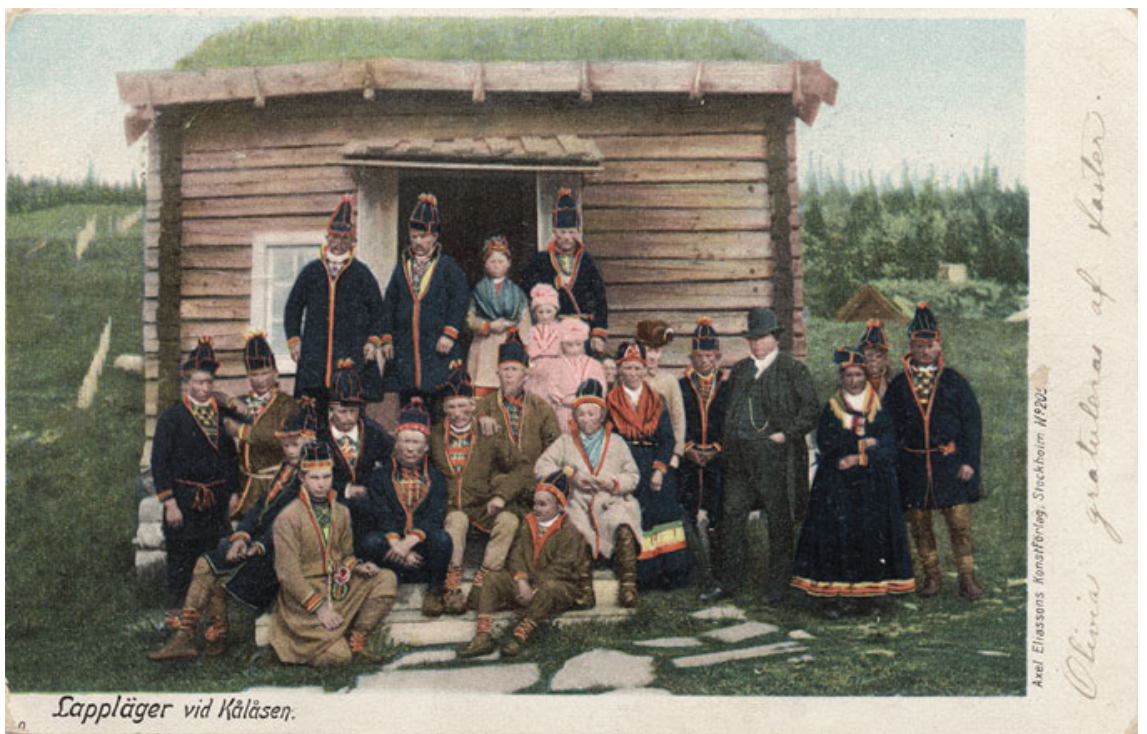

Fig. 6.4 'Lappläger vid Kolåsen' (Saami camp at Kolåsen). Photo Gösta Florman. Source Troms $\emptyset$ University Museum (tslp10803)

inaccurate. 'Saami camp' is perhaps one of the most frequent captions used on early Saami picture postcards. In most cases, it demonstrates a failure to understand the actual context.

The Kolås mass, which was held twice every summer, attracted Saami from far and near. Usually, the families would spend the weekend at Kolåsen. The church services, however, and all the Saami dressed in their festively coloured garments also attracted people from outside the congregation. The motif is recurrent in photographs and postcards, as were the other Saami chapels in Jämtland, such as Ankarede, Kolåsen, Jänmässholmen, Handöl and Vallbo. These chapels and Saami congregations, or lappförsamling, which is the Swedish term, were part of the Swedish Church's missionary policy towards the Saami in Jämtland and Härjedalen, which was initiated in the mid-1700s (Thomasson 2016). The congregations were non-territorial and the splitting up of the Swedish population meant that the Saami were excluded from belonging to the parish in which they lived. They could not vote locally as they were neither members of the local congregation nor the parish, their children could not go to local schools but were referred to nomadskolor (schools for nomads) and perhaps most importantly, according to Lars Thomasson who has studied the social and economic impact of the lappförsamling institution over 200 years and what it meant in terms of segregation, they were excluded from the local system of poor relief (Thomasson 2016, 855). The State and the Saami congregation were responsible for poor relief. I will return to this below as it has produced another photo motif particular to Sweden. There are different versions of the postcard of the people at the Kolåsen mass, both colourized and in black and white, and the people depicted have 
been identified by Lars Thomasson. The man in the suit and hat to the right in the photograph for example, is Anton Ådén, chaplain in Kall and pastores lapponum in Undersåker's lappförsamling between 1892 and 1909.

\subsection{Tourism, Live Ethnographic Displays and Postcards of South Saami}

Today, the ultimate Saami postcard features North Saamis in colourful costumes as represented in a Finnish postcard from the 1980s or 1990s by the Italian photographer Dino Sassi. ${ }^{22}$ Reindeer grazing on the marsh, the midnight sun, a boat pulled onto the shore of a lake, a couple in colourful North Saami costumes in front of a traditional Saami storage house on pillars surround the portrait of a man in the Enontekiö gákti which is basically the same as in Kautokeino in Norway. The characteristic starshaped hat and the sitter's weather-beaten and sunburnt face is the eye-catcher in the photograph. In Norway, festively dressed Saami from the interior of the county of Finnmark are particularly popular as a photo motif and especially from Kautokeino where the gákti has become more and more elaborate. The Kautokeino gákti with its highly pleated woollen dress and extensive use of thin and wide ribands is the most multi-coloured in all of Saepmie (Hætta 2013). A search using 'Kautokeino' in the Troms $\varnothing$ Museum Saami postcard collection resulted in 121 hits, most of them modern colour prints. At the turn of the nineteenth century, however, it is very likely that the person depicted would have been South Saami, like the anonymous young man captioned as Lappgosse (Saami boy) in a postcard from around 1900 (Fig. 6.5). As demonstrated below, the portrait is highly suggestive of personality and attitude. When I posted it on Facebook in an attempt to identify the sitter, several women commented on his beauty and how he resembled Erlend Elias Bragstad, a profiled Lule Saami stylist and gay activist.

One of the reasons for the public visibility of the South Saami at this time was the booming tourism industry and the extent to which the South Saami became involved in it, especially after the establishment of railroads in the 1880s, which made it easier to get into-and out of - parts of the South Saami area. As suggested by previous postcards, South Saami culture, or specific parts of it, was considered interesting and picturesque by outsiders due to the reindeer herding nomadic life style, the eyecatching costumes and the elaborate hats, such as the snijpetjohpe the young man is wearing, which stands out so nicely in the black-and-white photo along with the textures of the dress. Surely, the photographer was aware of this effect. For many years, the South Saami hats went out of style and have just recently been revitalized, mainly on the basis of photographs and postcards.

During the nineteenth century, South Saami who practised or engaged in nomadic reindeer husbandry became attractive to entrepreneurs who sought them out as subjects of 'live ethnographic displays' in Europe and the United States (Broberg 1981;

${ }^{22}$ Tslp11841. 
Fig. 6.5 'Lappgosse' (Saami boy). Postcard photographed and published by Nils Thomasson, Köfra. Source Troms $\emptyset$ Universitiy Museum (tslp10917)

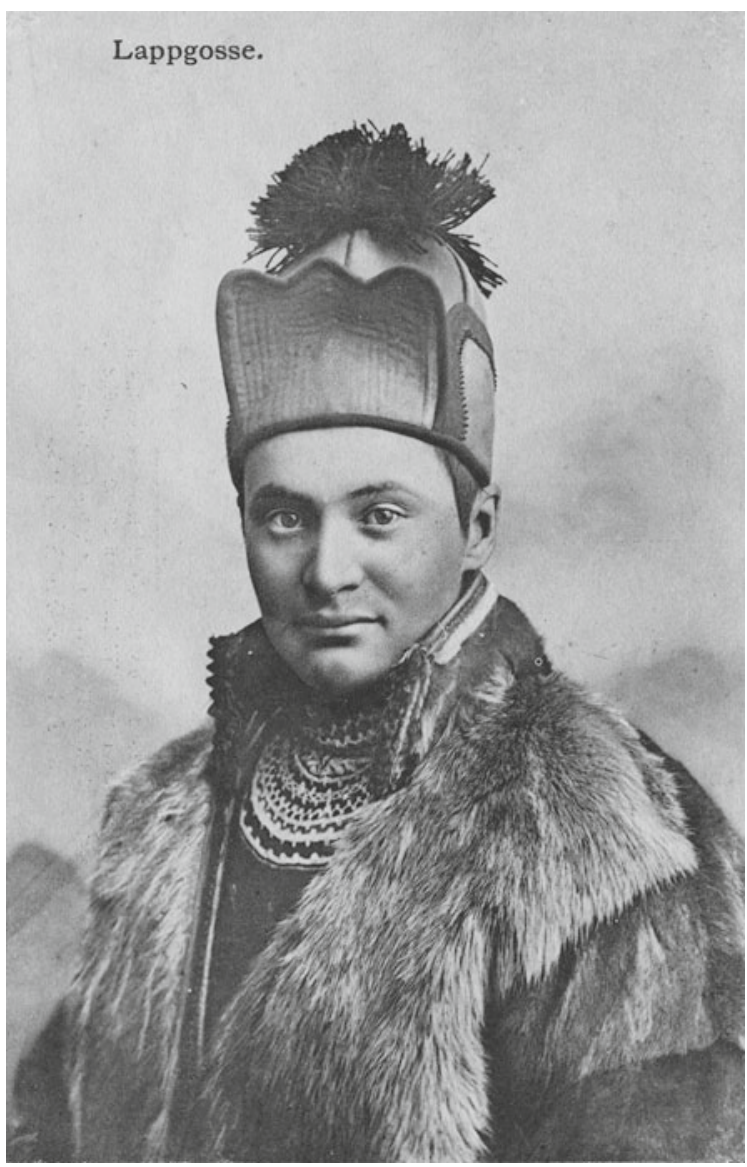

Gjestrum 1995; Baglo 2017). In the 1870s, when these displays became widespread, the attraction was directed towards the north, the reindeer herding North Saami, and places such as the Saami camp at Tromsdalen outside Troms $\varnothing$, which was accessible by boat only. In the 1880s and 1890s, due to the establishment of the railway, but also the increasingly challenging economic, political and cultural situation for the South Saami, they became dominant in this market which comprised exotic-appearing and so-called natural peoples from all over the globe. One of the many South Saami families that were involved in this business was Thomas Andersson, a South Saami born in Mosvika by the Trondheimsfjord in Norway. His parents had settled there after losing their reindeer in the mountains (Thomasson 1946, 265), a term frequently used in reference to the challenges that arose through colonial processes, but which obscures what this really meant in terms of the real sacrifice. At the age of 13, the family sent Thomas to a Saami school run by the Swedish Church Mission in Laxsjö in Jämtland. Later he settled in Oviken, south of Laxsjö, where he was able to make 
use of the reindeer mark he had inherited from his grandfather. The reindeer were few and herded by a neighbour but they were an important household supplement to the family which also ran a small farm in Svedje (Thomasson 1946, 266). Thomas Andersson's son, the photographer Nils Thomasson (1880-1975), produced the picture of the young Saami man and published the postcard from his studio in Kövra (Köfra) in Oviken.

\subsection{Nils Thomasson the South Saami Photographer}

By the time Thomasson produced and published the postcard Lappgosse, he had travelled extensively with his family in Europe, especially Germany and Southern Sweden as part of these types of live ethnographic displays where the Saami participants demonstrated the reindeer herding way of life in reconstructed settings. Thomasson was a boy and adolescent when this took place. On a postcard from one of the family's tours, Nils Thomasson is standing outside the låavth-gåetie (tent house) holding a pair of skis (Fig. 6.6). The caption reads 'A part of Lapland', which it is not, but who can tell? The background has been removed in compliance with the 'ethnographic convention' (Smith and Joppien 1985), and what has been removed is most likely an urban setting in Hamburg, Schneidemühl (Piła in Polish), Visby or some other city or town the group is known to have visited.

The purpose of the live ethnographic displays was to recreate a 'true copy of natural life' (Hagenbeck 1911, 49). The ethnographic convention in images was driven by a scientific interest in the sitter, employing neutral backgrounds and full-length, facingforward views to convey knowledge about the dress and material culture of distant peoples. The sitters in such imagery, together with their clothing and tools with which they are pictured, are typically meant to stand in for their cultures at large. By erasing the background, however, the sitters appear disconnected from time and space. The experiences of the Thomasson family abroad become invisible.

As pointed out by James Clifford (2007), the conception of indigenous cultures as invariable and static has obscured travelling, contact and migration even though the fact is that geographic mobility - self-elected or forced-has always taken place. Much like postcards, the live ethnographic displays are often perceived in negative terms as technologies of exploitation and oppression only, but they also represented access to social, political and economic means in a colonial situation (see for example, Moses 1996; Raibmon 2005; Penny 2013; Baglo 2017). Beyond doubt, the presenters' travels and encounters had great impact on them as well as their native communities. It would be fair to say that among the lessons learned, they must have gained particular knowledge about how to present their culture and cultural distinctiveness to an outside public. Just like the displays, postcards and photography represented means of conveying something you were proud of, something you wanted to let the world know about. The Saami and the Saami way of life were of key importance in Nils Thomasson's work as a photographer. Indeed, Thomasson's photography has been paramount to Swedish Saami self-esteem (Silvén 2018). He 


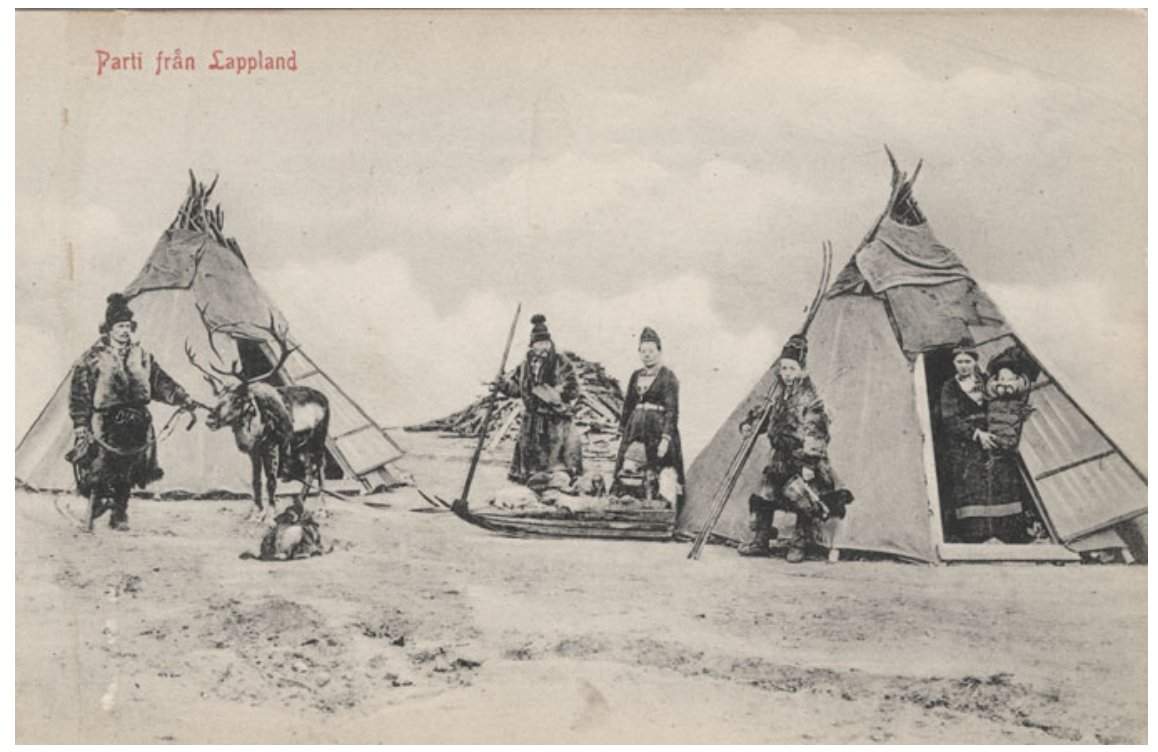

Fig. 6.6 'Parti från Lappland' (A part of Lapland). The young Nils Thomasson (1880-1975) is holding a pair of skis. Most of the people depicted are Thomasson's family, including his father, brother and stepmother. Source Troms $\varnothing$ Universitity Museum (tslp10812)

received apprenticeship training with the photographer Olof Östling in Gävle, a city by the Baltic Sea, in the late 1890s. Afterwards, he moved back to Kövra where his father had built a studio for him. Thomasson later moved his studio to Åre, a village and growing mountain resort some $100 \mathrm{~km} \mathrm{NW}$ of Kövra, where he settled permanently in 1916 (Utsi 1997).

The tropes of Saami postcards from the late nineteenth and early twentieth centuries and the tropes and configurations of the live ethnographic displays in the same period are strikingly similar. They both dramatize the authentic, the picturesque, the radically different but also universally similar, and the family unit, the reindeer herding life with its seasonal migration, work, handicrafts and daily life were important elements in both modes of representation (for the presentation of Saaminess in the live ethnographic displays, see Baglo 2017, 190-202). Moreover, live ethnographic displays often became motifs on postcards. The organizer, but very often the Saami presenters themselves, would sell postcards and photographs to spectators as souvenirs or as advertisements for the show in addition to the sale of Saami handicraft (Baglo 2008, 33). The Saami camp ${ }^{23}$ and the different kinds of housing for the various

\footnotetext{
${ }^{23}$ A search using "camp" in the Tromsø Museum Sámi postcard collection gave 49 hits, a search using "settlement" gave the same (many overlaps). A search using "Sami camp" gave 62 hits. When classifying, the term was used to distinguish commercial camps from other camps such as camps organised by Norwegian mountain hotels.
} 
seasons $^{24}$ constitute a prevailing motif. The camps were located on Saami lands or transported and reconstructed outside mountain resorts such as Grotli Hotel in Sjåk in Central Norway, ${ }^{25}$ in cities and in exhibition spaces in Sweden or Norway or in cities and exhibition grounds abroad. These were some of the possibilities tourism and modern society generated. The concurrent motifs testify of course to the existence of an international genre in the representation of indigenous cultures independent of historical and geographical contexts. Although cultural distinctiveness fuelled the industry, the representations were simultaneously streamlined in the same colonial machinery.

The family was an important trope, providing a cognitive framework that had the great advantage of being understood by all potential spectators and audiences and was a recurrent motif on postcards, in addition to serving as a category of live ethnographic display. Sometimes, the category was imposed. The postcard 'Lappefamilie' (Saami family) shows in fact a South Saami troupe during a tour, probably in Germany (Fig. 6.7). Many, but not all of the Saami presenters were related. The young girl in the tjurrietjohpe and shawl is Maria Thomina Thomassen from Anaris Mountains. Later, she moved to Bydalen mountains in what is now Åre municipality in Jämtland in central Sweden. Her parents and some of her siblings are probably in the photograph as well. The family participated in several live ethnographic displays abroad in the late 1880s and early 1890s. In 1890, her father was listed as poor in the house enquiry register of Undersåker Saami Congregation in 1890. The family was at this point lodging with the congregation's catechist.

Maria Thomasson became a recurring motif on postcards and photographs. One who took her portrait was Nils Thomasson from his studios in both Åre and Köfra. ${ }^{26}$ Köfra is not far from Anaris and the mountain resort of Bydalen where Maria Thomasson resided. Either he or some other entrepreneur has sought her out, or she has appointed him to produce the photograph. In addition to his work as a portrait photographer, Thomasson produced pictures for tourists, not least the yearly journal of the Swedish Tourist Association where he contributed regularly. One of his portraits of Maria Thomasson is taken from the side resembling anthropological photographs where the profile of the face and head was important. More important, however, seems to be the fact that a picture in profile pays justice to the hat and the characteristic tjurrie - the crest or comb. A less emphasized side to Thomasson's work is his collaboration with Herman Lundborg and the Swedish State Institute for Racial Biology in the 1910s and 1920s (Broberg 1990, 138; Silvén 2018). Lundborg was the head of the institute, and recently he has been portrayed in the critically acclaimed

\footnotetext{
${ }^{24}$ A search using "tent" (lavvu) in the Tromsø Museum Sámi postcard collection gave 162 hits, a search using "buesperretelt" (a tent rafted a particular kind of way) gave 102 hits, "gamme", a Norwegian term derived from North Sámi referring to the turf hut gave 319 hits, "kåte", the same word in Swedish but derived from South Sàmi gave 247 hits, a search using "stillas" or "luovve" (scaffold) gave 72 hits, a search using "stabbur", "njalla" or "aitti" (small storage house, often on pillars) gave 119, 38 and 1 hits, respectively. Many of these hits overlap.

${ }^{25} 18$ postcards in the Troms $\varnothing$ Museum collection are from Grotli. Many of them have been photographed by I.K. Maurseth and show the North Saami family Partapuoli.

${ }^{26}$ See for example, pp. 40, 58 and 64 in Samefotografen Nils Thomasson (1997).
} 


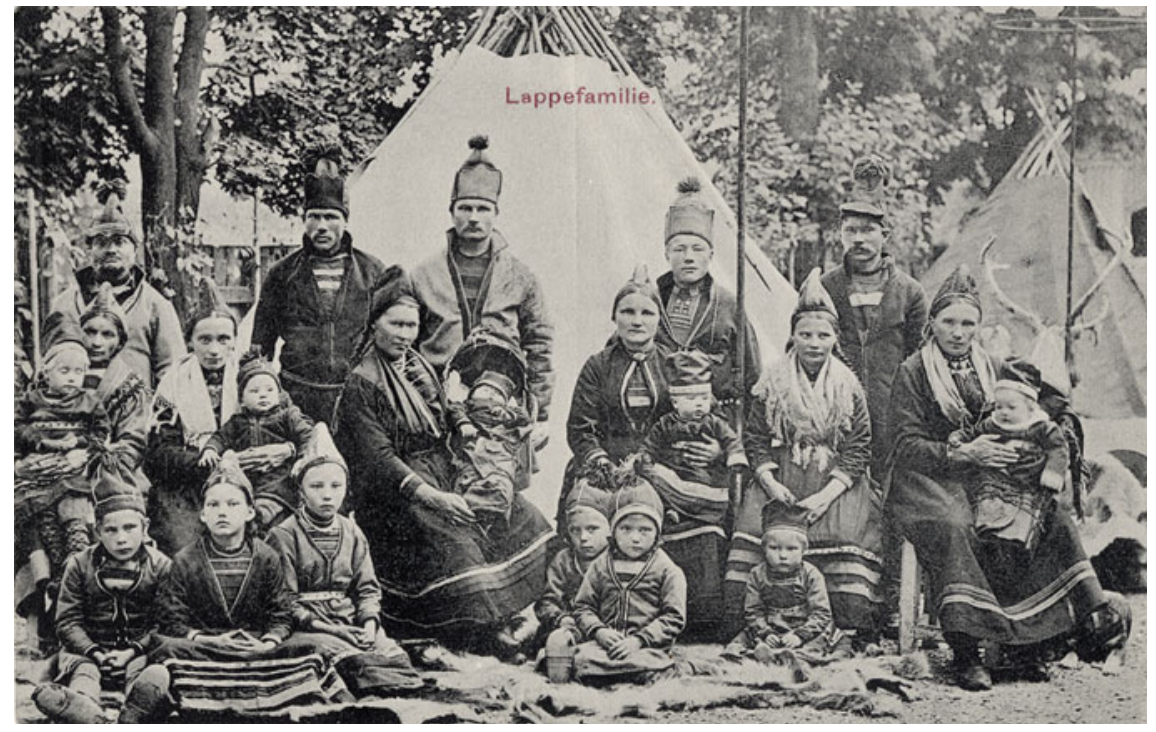

Fig. 6.7 'Lappefamilie' (Saami family). Maria Thomina Thomassen (1873-1935) to the right with shawl and hands folded in her lap. Source Tromsø University Museum (tslp13267)

movie Sameblod (Saami blood) by Amanda Kernell (2017). Among other tasks, Thomasson delivered or produced photographs for Lundborg's book Swedish Folk Types (Svenska folktyper) published in 1919, and in 1925 he contributed to one of Lundborg's physical anthropological examinations (Jonsson 2008, 116-120). One of the eight photographs by Thomasson in Swedish Folk Types is the same photograph as the postcard 'Lappgosse'. In the book, it bears the title 'Jämtlandsk lappgosse' (Saami boy from Jämtland) (Fig. 6.8). As pointed out by Swedish ethnologist Eva Silvén, more than anything else, this demonstrates the hegemonic position of racial biology as normal science, both at the time and much later (Silvén 2018).

While Thomasson in many ways, and particularly in the early phase, reproduced ethnographic conventions and stereotypical, romanticizing ideas about the Saami, his photographs also helped to create a Saami identity and positive sense of self. His photographs are intimate and personal in nature and often his own children-he had eight - constituted the sitters. This is the case with a postcard based on a photograph from around 1933-1934 (Fig. 6.10). The girl holding the young reindeer calf is Aina Thomasson (b. 1923) while the young boy gently caressing it is the already mentioned Lars Thomasson (b. 1928), later a profiled scholar and a driving force in Saami organizational life in Sweden since the post-war period (see for example, Frånberg et al. 2007). After 1920, and with the improvement of photographic technology, the compositions of photographic postcards became livelier and more visually interesting (Ulvestad 2005). One example is Thomasson's postcard 'Fjellfåglar' (the mountain birds) where two cheerful South Saami boys have climbed up a tree (tslp11115). The landscape often added a dramatic dimension to the portraits as well as the play with 


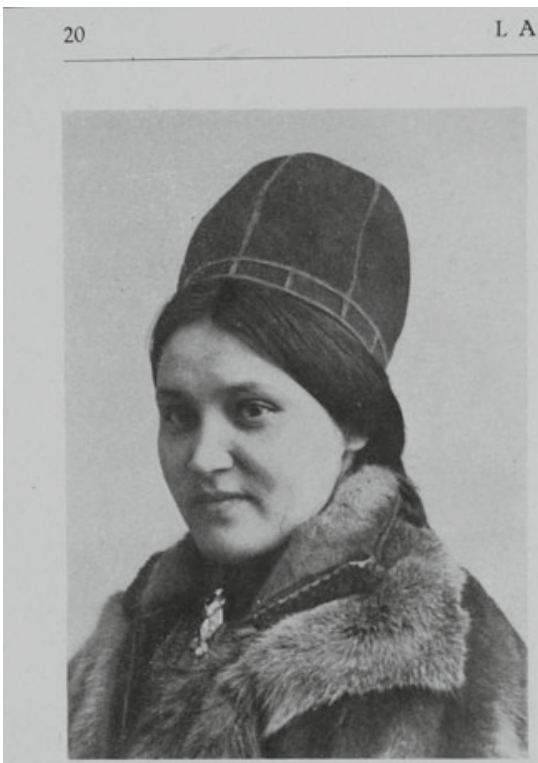

Typisk jämtlandslapska.

Foto. N. Tomasson, Are.

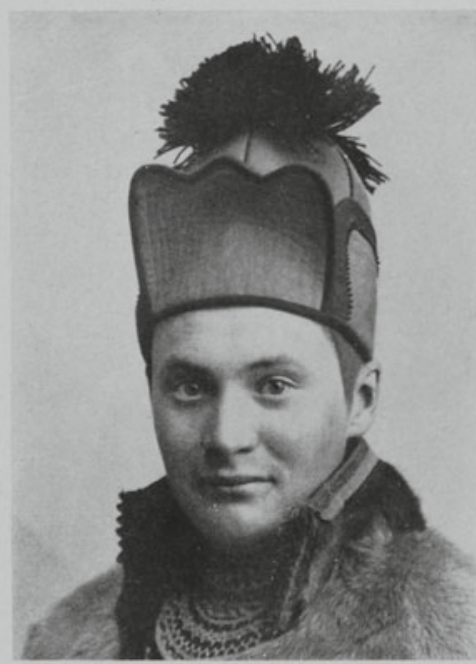

Jämtländsk lappgosse.

Foto. N. Tomasson, Are.

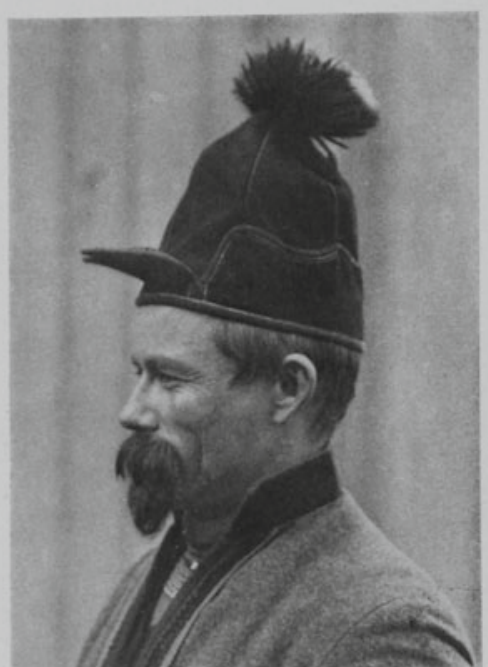

Jämtlandslapp av lapskesvensk typ.

Foto, N, Tomasson, Are.

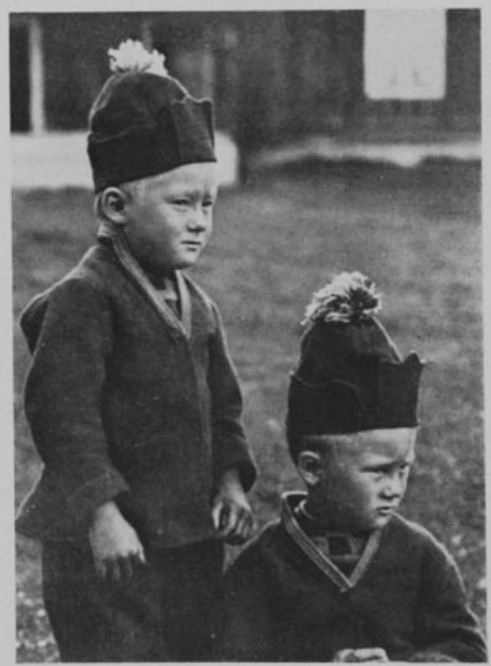

Tvà jämtländska lappgossar (tvillingar).

Foto. N. Tomasson, Are.

Fig. 6.8 Photographs by Nils Thomasson in H. Lundborg's 'Swedish Folk Types' (1919) 
light, shade and textures. The picture postcard, 'Renvaktare' (the reindeer herder) showing a young boy with his lasso, backpack and herding dog, both looking into the distance, can be interpreted as a demonstration of the vitality of Saami culture (Fig. 6.9). It is not vanishing. The new generation is being prepared to take over.

Another motif particular to Swedish postcards has been the nomadic school. According to the authorities, it should be in a gåatie (a circular or oval dwelling with framework of wood and tree trunks and covered with turf). Particular buildings resembling the gåetie were sometimes constructed for the purpose (see tslp10358, the nomadic school in Kiruna). The children stayed at the school for periods of time, after the 1896 regulation, 36 weeks a year for 5 years (Blind 2015, 74). In some areas, classes were divided between different schools so that siblings could be separated from each other. In Jämtland in the 1940s and 50s for example, the children's first 2 years took place in Mittådalen, the middle years at Jänsmässholmen and the last years at Änge (Thomasson 2015, 123). Initially, the nomadic school was an attempt by the authorities to make Saami who had become sedentary to return to the nomadic life and the kind of reindeer herding they considered appropriate for the Saami, and in other words, the mountain Saami way of herding, not the forest Saami, who were also more in conflict with agricultural and lumbering interests. The nomadic school, just as the Lap-should-be-Lap ideology developed by the Swedish authorities from the last part of the nineteenth century and coined for the first time in 1906 by Vitalis Karnell, a vicar working in Karesuando, created some, at best, absurd scenarios, such as the bewilderment of a young girl from Leaváš sameby in the outskirts of Kiruna. Her family had just moved into a timber house with beds and linens, but at the
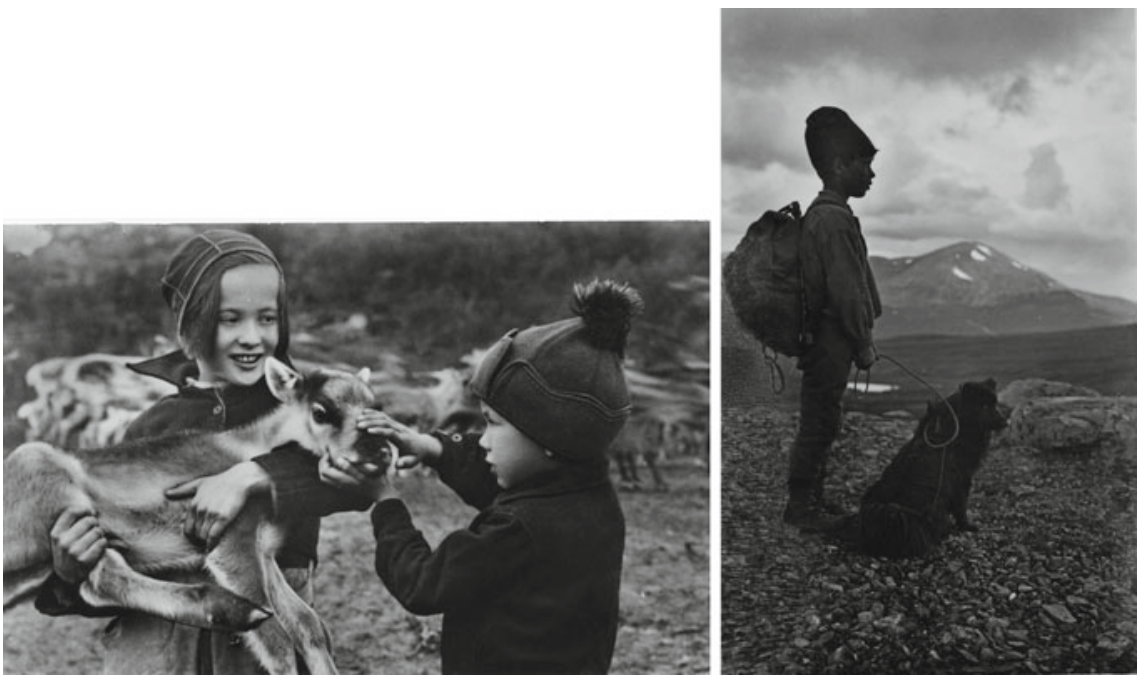

Fig. 6.9 Postcards produced by Nils Thomasson. The photograph to the left show two of the photographer's own children, Aina (b. 1923) and Lars Thomasson (b. 1928). Source Troms $\varnothing$ University Museum (tslp12590 and tslp12650) 
nomadic school she had to sleep on birch branches on a dirt floor (Huuva 2015, 35). In the article, 'Lapparna och civilisationen' (The Lapps and civilization) in Dagny, a journal for the Swedish women's movement, Karnell wrote the following:

When a Lapp man or a Lapp woman starts walking around in Stockholm in more or less mismanaged Lapp costumes, when the Lapps start establishing their own organisations and their own newspaper, when they start acquiring elementary school education, then their days as Lapps are over and they become the most miserable people you can possibly imagine. (Karnell 1909 in Huuva and Blind 2015, 83)

Although an arduous and painful experience for many families and children (see for example, Huuva and Blind, ed. 2015), the schools also contributed to bolstering Saami traditions. Two postcards of nomadic schools in the Troms $\emptyset$ Museum collection have been photographed and produced by Nils Thomasson. Both show playful, happy children. Another, at least to an outsider, peculiar motif among Thomasson's postcards is the old people's home 'Fjällgård' (Mountain homestead) in Hålland built by the Female Missionary Workers Association in 1908 for the Saami exclusively (Fig. 6.10). Several variations of this motif exist as a postcard, almost all of them produced by Thomasson, perhaps to raise money for the organization. Most of them carry the same caption: 'Fjällgård. K.M.A:s Ålderdomshem för Jämtlandslappar, Hålland'. The institution was discontinued in 1981 and judging by Nils Thomasson's many renderings of the building and activities related to it during all these years among the 11,408 photographs in his collection at Jamtli in Østersund, ${ }^{27}$ it was an important part of the Saami community. In the postcards, the old people's home is brand new and evidently something to be proud of and grateful for. In one postcard, three women are sitting outside on benches along the timber wall. It is a sunny summer day. The women are all dressed in Saami costumes, their hands are resting folded in their laps. The latticed white windows are wide open. ${ }^{28}$ It seems like a good place to be.

The atmosphere is quite different in the postcard 'Bofasta lappar från Stensele' (Sedentary Saami from Stensele) despite the summery motif (Fig. 6.11). Stensele is a locality in Storuman municipality in Västerbotten in Sweden. The postcard belongs to the series 'Sverigebilder' (Swedish images) published by the Swedish Tourist Association in 1926 and shows a large family standing on the stairs of their timber house. None of the seven children are wearing shoes. Apart from the grandfather, all are wearing ordinary clothes, although the father is wearing Saami shoes. In contrast to for example, the photographs of Nils Thomasson, the postcard leave little doubt regarding the relations of power separating the photographer, G. Sandgren, from his subjects. The mother stares with suspicion into the camera lens. One girl is peeping out from behind her sisters standing close to her mother. Some of the children are bending their necks out of modesty or shame. Only the grandfather seems to be at ease with the situation. This is a portrait of poverty and the fait accompli of a public policy that would create a large 'underclass' of Saami without reindeer, a situation that still impacts the identity of young Saami today (Åhren 2008).

\footnotetext{
${ }^{27} \mathrm{http}$ ://bildarkivet.jamtli.com/sok.aspx?fenamn=nils+thomasson.

${ }^{28}$ Tslp10292. The motif is found in Alain Borvo's collection as well.
} 


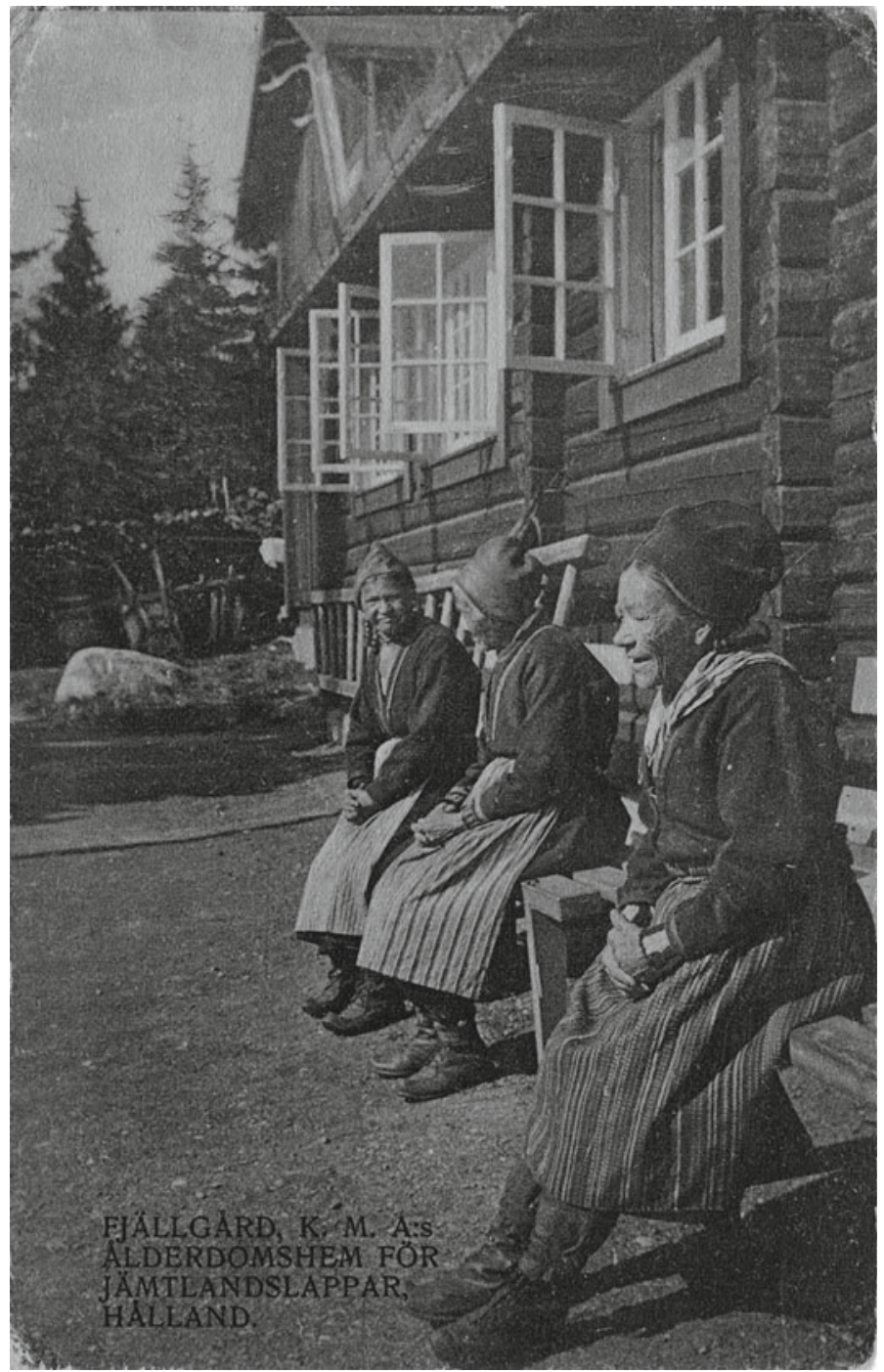

Fig. 6.10 Fjällgård. K.M.A:s Ålderdomshem för Jämtlandslappar, Hålland. Photo: N. Thomasson. (Mountain farmstead in Hålland. The old people's home for Saami from Jämtland run by The Female Missionary Workers Association). Source Troms $\varnothing$ University Museum (tslp10292) 


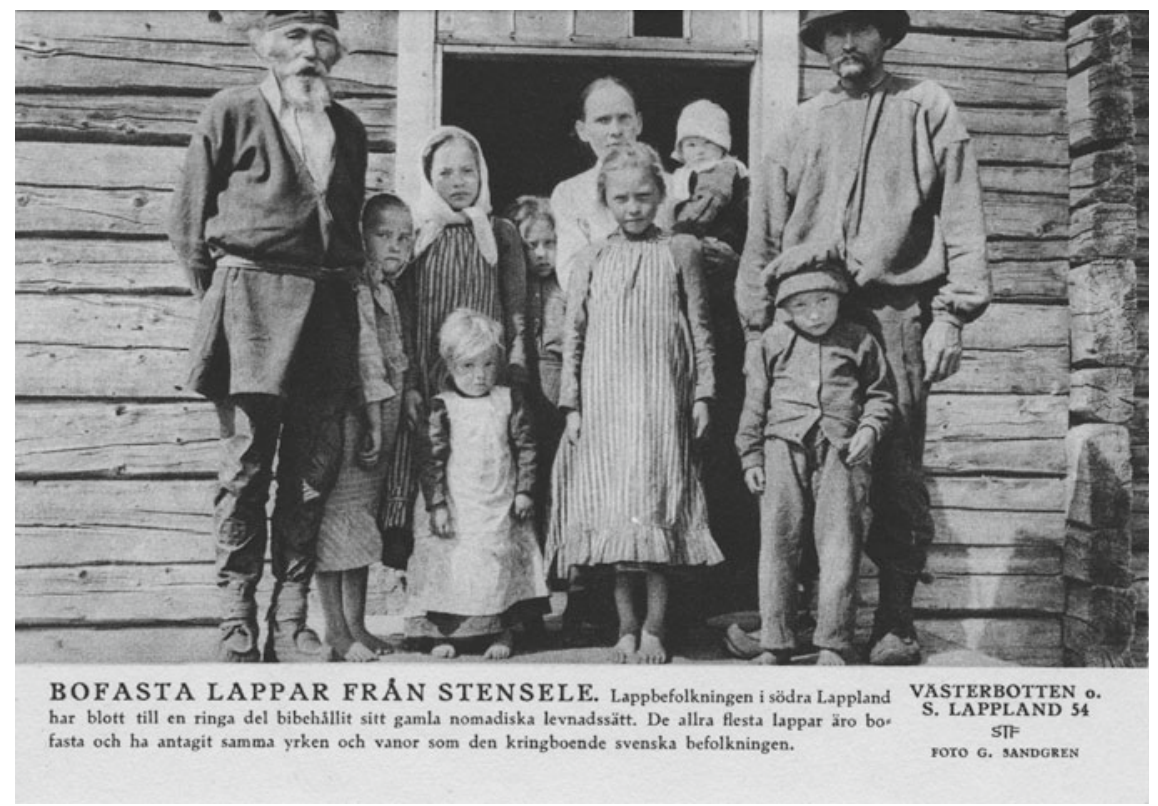

Fig. 6.11 'Bofasta lappar från Stensele' (Sedentary Lapps from Stensele). Photo G. Sandgren. Source Troms $\emptyset$ University Museum (tslp10168)

\subsection{Postcards to Puncture Blindness and Lessen Loss}

In this chapter, I have shown motifs and tropes in picture postcards of South Saami from approximately 1880-1950. While the South Saami was highly visible on postcards during this time, especially the first decades, they gradually vanished out of sight. At this time, the postcard market was primarily oriented towards the Swedish South Saami. Just like the live ethnographic exhibitions, race is for the most part articulated through the use of typologies and typologically classifying gazes and poses. On occasion, the motif itself, such as 'Lappgosse', undermined the racial message by suggesting personality and attitude. Moreover, the gradual assimilation and obliteration of South Saami culture has taken place hand in hand with the romanticizing of it. It has also been demonstrated here how early picture postcards of South Saami articulate the same tropes and aesthetics as identified across a wide range of colonial visuals, including the live ethnographic displays. Common denominators for these are the construction of stereotypes and erasure of difference. While landscape was considered a key to understanding the characters of both peasants and 'natural peoples' in the nineteenth century, this perception would persist only in relation to the latter. Savage peoples were per definition subjected to or living in harmony with nature, while civilization and progress was synonymous with severance. The strong focus on nature in the postcards of South Saami granted both authenticity and identity to the sitters. It is important to acknowledge, however, that the postcard 
industry had its own dynamic, which was to a great extent related to other-and partly concurrent-perceptions of nature and culture than those asserted by science, such as the emphasis on families and sameness. What I have also aimed to demonstrate in this chapter is the importance of early picture postcards to reclaim stories, imagery and knowledge that have remained hidden or lost and consequently open for discussions of colonization and decolonization. Due precisely to their 'unruliness', early picture postcards may diversify, expand and complicate our perception of northern colonialism and the Saami response to it. The large number and variety of postcards adds to the unruliness, which has gained particular momentum due to digitization. In recent years, a more nuanced perception of ethnographic photography and early picture postcards has surfaced, fuelled by such theoreticians as Elizabeth Edwards, who emphasize the importance of photographs as material entities with qualities and agency of their own, rather than being just signs or symbols of ideologies and social structures (see for example, Edwards 2002, 2005, 2010; Baglo 2012). While photographs are images, they are also objects, and this materiality is integral to their meaning and use (Edwards and Hart 2004). As pointed out by Nuño Porto, the possibility of thinking about ethnographic photographs rests on the elemental fact that they are things - 'they are made, used, kept, and stored for specific reasons which do not coincide [...] they can be transported, relocated, dispersed, are damaged, torn and cropped, and because viewing implies one or several physical interactions' (Porto 2001, 38). In an article on processes of repatriation of Saami photographs from Finnish archives and museums, Saami historian Veli Pekka Lehtola demonstrates that contemporary Saami approaches to historical photographs emphasize subjective, localized experiences and the way they evoke memories of 'intraethnic' relationships (Saami-Saami) or 'our histories', where previous interpretations emphasized power relations and what he identifies as 'inter-ethnic' (Finnish-Saami) relationships (Lehtola, forthcoming). In doing so, the Saami often look beyond the photograph's historical context. The Finnish and colonial 'mark' on the photography is not ignored, but it is subordinate to what the photographs might reveal in terms of Saami history. As Lehtola has done, a growing body of research has strived to 'flip the lens' back to overshadowed photographic practices (Pedri-Spade 2016). By grounding photography within indigenous peoples' creative practices, the picture postcards have become an expression of agency that indigenous communities use, and have used, to achieve different goals linked to confronting and countering colonialism and its ongoing legacy. 'Our pictures are good medicine,' anthropologist Celeste Pedri-Spade recently expressed in an article on the role of historical photographs in her Anishinabe community in Ontario in Canada (Petri-Spade 2016). For non-Saami or non-indigenous community members, encounters with ethnographic photographs and picture postcards from our collective past may also have important effects. 


\section{Bibliography}

Åhren, Christina. 2008. Är jag en riktig same?: En etnologisk studie av unga samers identitetsarbete. Ph.D. Dissertation. Umeå universitet, Humanistisk fakultet, Institutionen för kultur- och medievetenskaper.

Alloula, Malek. 1986. The colonial harem. Minneapolis: University of Minnesota Press.

Baglo, Cathrine. 2001a. Vitenskapelige stereotypier: Om konstruksjonen av samene som kulturhistorisk enhet i tida fram mot 1910. Master's degree thesis in archaeology, University of Troms $\varnothing$.

Baglo, Cathrine. 2001b. From universal homogeneity to essential heterogeneity: On the visual construction of 'the Lappish race'. Acta Borealia 2: 23-39.

Baglo, Cathrine. 2008. Visualisations of the 'Lappish Race': On photographs and exhibitions of Sámi in Europe in the period 1875-1910. In Looking North: Representations of Sámi in visual arts and literature, ed. Heidi Hansson and Jan-Erik Lundström. Umeå: Bildmuseet/Umeå University and Främmande Nord.

Baglo, Cathrine. 2012. Fotografiers materialitet: Bilders betydning for forestillinger om samisk kulturell fremmedhet. Tidsskrift for kulturforskning 3: 45-61.

Baglo, Cathrine. 2014. Rethinking Sami Agency during living exhibitions: From the age of empire to the postwar period. In Performing Indigeneity: Global Histories and Contemporary Experiences, ed. Laura H. Graham and H. Glenn Penny. Lincoln \& London: University of Nebraska Press.

Baglo, Cathrine. 2017. På ville veger? Levende utstillinger av samer i Europa og Amerika. Stamsund: Orkana forlag.

Blind, Ellacarin. 2015. Trehundra år av samisk skolhistoria. In När jag var åtta år lämnade jag mitt hem och jag har ännu inte kommit tilbaka: Minnesbilder från samernas skoltid, ed. Kaisa Huuva and Ellacarin Blind. Stockholm: Verbum AB.

Broberg, Gunnar. 1981-82. Lappkaravaner på villovägar: Antropologin och synen på samerna fram mot sekelskiftet 1900. Lychnos 27-86.

Broberg, Gunnar. 1990. Bakom och framför kameran. Västerbotten 2: 136-147.

Clifford, James. 2007. Varieties of indigenous experience: Diasporas, homelands, sovereignities. In Indigenous experience today, ed. Marisol de la Cadena and Orin Starn, 197-224. Oxford and New York: Berg Publications.

Edwards, Elisabeth (ed.). 1992. Anthropology and photography 1860-1920. New Haven and London: Yale University Press.

Edwards, Elisabeth. 2002. Raw histories: Photographs, anthropology, and museums. Oxford: Berg.

Edwards, Elizabeth. 2005. Photographs and the sound of history. Visual Anthropological Review 1-2: 27-46.

Edwards, Elizabeth. 2010. Photographs and history: Emotion and materiality. In Museum materialities: Objects, engagements, interpretations, ed. Sandra H. Dudley. New York and London: Routledge.

Edwards, Elizabeth, and Janice Hart. 2004. Photographs objects histories: On the materiality of images. London and New York: Routledge.

Edwards, Elizabeth, and Sigrid Lien. 2014. Uncertain images: Museums and the work of photographs. London: Routledge.

Faris, James C. 2003. Navajo and photography: A critical history of the representation of an American People. Salt Lake City: The University of Utah Press.

Frånberg, Per, Peter Sköld, and Per Axelsson. 2007. Från Lars Thomassons penna. Biografiska anteckningar 1956-2006. Umeå: Centrum för Samisk forskning.

Geary, Christaud M., and Virginia-Lee Webb. 1998. Delivering views: Distant cultures in early postcards. Washington DC: Smithsonian Institution.

Gjestrum, Jon Åge. 1995. Utstilling av levende mennesker: En historie om samisk kultur og fremmede blikk. Dugnad 1:93-109.

Hætta, Inga Hermansen. 2013. Kautokeino-kofta. In Norsk Bunadsleksikon, ed. Bjørn Sverre Hol Haugen. Oslo: Cappelen Damm.

Hagenbeck, Carl. 1911. Dyr og mennesker. København: Gyldendalske Boghandel/Nordisk Forlag. 
Høvik, Ingeborg. 2016. Reproducing the indigenous: John Møller's studio portraits of Greenlanders in context. Acta Borealia 2:166-188.

Huuva, Susanna. 2015. Susanna Huuvas berättelse. In När jag var åtta år lämnade jag mitt hem och jag har ännu inte kommit tilbaka: Minnesbilder från samernas skoltid, ed. Kaisa Huuva and Ellacarin Blind. Stockholm: Verbum AB.

Huuva, Kaisa, and Ellacarin Blind. 2015. När jag var åtta år lämnade jag mitt hem och jag har ännu inte kommit tilbaka: Minnesbilder från samernas skoltid. Stockholm: Svenska Kyrkan.

Jonsson, Johan. 2008. “Samer i bild - bilder av samer. Ett fotografi och tre berättelser.” In För Sápmi i tiden (Fataburen), ed. Christina Westergren and Eva Silvén. Stockholm: Nordiska Museet.

King, J.C.H., and Henrietta Lidchi (eds.). 1998. Imaging the Arctic. Seattle/Vancouver: University of Washington Press/UBC Press.

Kjeldstadli, Knut. 2010. Fra innvandrere til minoriteter. In Nasjonale Minoriteter i det flerkulturelle Norge, eds. A.C. Bonnevie Lund, B. Bolme Moen. Trondheim: Tapir Akademisk forlag.

Lantto, Patrik. 2000. Tiden börjar på nytt. En analys av samernas etnopolitiska mobilisering I Sverige 1900-1950. Umeå: Kulturens Frontlinjer. Skrifter från forskningsprogrammet Kulturgräns i Norr.

Larsen, Peter, and Sigrid Lien. 2007. Norsk fotohistorie: Frå daguerrotypi til digitalisering. Oslo: Det norske samlaget.

Lehtola, Veli-Pekka. 2018. 'Our histories' in the photographs of the others. Sámi approaches to visual materials in archives. In Journal of Aesthetics and Culture, ed. Sigrid Lien (thematic issue on Sámi Representations, forthcoming).

Lien, Sigrid. 2017. Assimilating the wild and the primitive: Lajla and other Sámi heroines in Norwegian fin-de-siécle photography. In Disturbing pasts: Memories, controversies and creativity, ed. Leon Wainwright. Manchester: Manchester University Press.

Lien, Sigrid, and Nielsen, Hilde. 2012. Absence and presence: The work of photographs in the Sàmi Museum, RiddoDuoattarMuseat-Sámiid Vuorká-Dávvirat (RDM-SVD) in Karasjok, Norway. Photography and Culture.

Maxwell, Anne. 1999. Colonial photography and exhibitions: representations of the "native" and the making of european identities. London: Leicester University Press.

Minde, Henry. 2005. Fornorskinga av samene - hvorfor, hvordan og hvilke følger? Gáldu Čála. Tidsskrift for urfolks rettigheter 3: 5-20.

Moses, L.G. 1996. Wild West shows and the images of American Indians 1883-1933. Albuquerque: University of New Mexico Press.

Pedri-Spade, C. 2016. Waasaabikizo: Our pictures are good medicine. Decolonization: Indigeneity, Education \& Society 5(1):45-70.

Penny, H.Glenn. 2013. Kindred by choice: Germans and American Indians since 1800. Chapel Hill: The University of North Carolina Press.

Poole, Deborah. 1997. Vision, race, and modernity: A visual economy of the Andean image world. Princeton and New Jersey: Princeton University Press.

Porto, Nuño. 2001. Picturing the museum: Photography and the work of mediation in the Third Portuguese Empire. In Academic anthropology and the museum, ed. M. Bouquet, 36-54. Oxford: Berghan.

Raibmon, Paige. 2005. Authentic Indians: Episodes of encounter from the late-nineteenth-century northwest coast. Durham and London: Duke University Press.

Rydell, Robert. 1998. Souvenirs of imperialism. In Delivering views: Distant cultures in early postcards, ed. Christraud M. Geary and Virginia-Lee Webb. Washington and London: Smithsonian Institution Press.

Silvén, Eva. 2018. Friktion: Ernst Manker, Nordiska museet og konstruktionen av ett samiskt kulturarv. Forthcoming.

Smith, Barnard, and Rüdiger Joppien. 1985. The art of captain cook's voyages: The voyage of the endeavour 1768-1771. Melbourne: Oxford University Press.

Thomasson, Nils. 1946. En fjällets man. In Min far: Trettioen svenska män och kvinnor om sina fader, ed. Ivan Oljelund. Uppsala: Lindblads Förlag. 
Thomasson, Lars. 2015. Samebarns skolgång i en brytningstid. In När jag var åtta år lämnade jag mitt hem och jag har ännu inte kommit tilbaka: Minnesbilder från samernas skoltid, ed. Kaisa Huuva and Ellacarin Blind. Stockholm: Verbum AB.

Thomasson, Lars. 2016. Lappförsamlinarna i Jämtland-Härjedalen 1746-1941. Gemenskap eller segregering? In De historiska relationerna mellan Svenska kyrkan och samerna: En vetenskaplig antologi, ed. Daniel Lindmark and Olle Sundström, band 2. Skellefteå: Artos \& Norma bokförlag.

Ulvestad, Ivar. 2005. Norske Postkort. Kulturhistorie og samleobjekter. Oslo: N.W. Damm \& Søn.

Utsi, John E. 1997. Samefotografen Nils Thomasson. Östersund: John E. Utsi and Jamtli förlag/Jämtlands läns museum.

Valkeapää, Nils Aslak. 1983. Greetings from Lapland: The Sámi-Europe's forgotten people. London: Zed Press.

Woody, Howard. 1998. International postcards: Their history, production, and distribution (Cirka 1895-1915). In Delivering views: Distant cultures in early postcards, ed. Christraud M. Geary and Virginia-Lee Webb. Washington and London: Smithsonian Institution Press.

Open Access This chapter is licensed under the terms of the Creative Commons Attribution 4.0 International License (http://creativecommons.org/licenses/by/4.0/), which permits use, sharing, adaptation, distribution and reproduction in any medium or format, as long as you give appropriate credit to the original author(s) and the source, provide a link to the Creative Commons licence and indicate if changes were made.

The images or other third party material in this chapter are included in the chapter's Creative Commons licence, unless indicated otherwise in a credit line to the material. If material is not included in the chapter's Creative Commons licence and your intended use is not permitted by statutory regulation or exceeds the permitted use, you will need to obtain permission directly from the copyright holder.

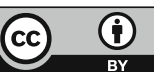

